\title{
Foliar Applications of Calcium and Boron Do Not Increase Fruit Set or Yield in Northern Highbush Blueberry (Vaccinium corymbosum)
}

\author{
Matthew Arrington' ${ }^{1}$ and Lisa Wasko DeVetter ${ }^{2,3}$ \\ Department of Horticulture, Washington State University, Northwestern \\ Washington Research and Extension Center, 16650 State Route 536, \\ Mount Vernon, WA 98273
}

Additional index words. bloom, fertility, plant nutrition, pollination

\begin{abstract}
Fruit set in northern highbush blueberry (Vaccinium corymbosum L.) can be low under certain climatic conditions, contributing to reduced yields in northwestern Washington. The mechanisms influencing fruit set are complex, but reduced fruit set may be associated with inadequate nutrient availability during critical stages of flowering, ovule fertilization, and initial fruit development. Calcium (Ca) and boron (B) are of particular interest for reproductive developmental processes and are frequently applied annually by growers in the Pacific Northwest region because of the perception that these nutrients enhance fruit set and corresponding yields. Evaluation of commonly applied products containing these nutrients and their effects on fruit set and yield are of specific importance to justify the application of these nutrients. To address this, commercially available fertilizers containing $\mathrm{Ca}$ and $\mathrm{B}$ were applied to 'Draper' and 'Bluecrop' blueberry as foliar sprays, either alone or in combination, during the 2015 and 2016 growing seasons in northwestern Washington. Treatments included calcium chloride (750 and $1500 \mathrm{ppm} \mathrm{Ca})$, calcium sulfate (150 ppm Ca), and tetra borate (125 and $250 \mathrm{ppm}$ B) foliar sprays, repeated six times per season every 7-10 days from early pink bud through petal fall. No significant increases were observed for fruit set, estimated yield, and fruit quality (firmness and berry weight) across the treatments. Increased concentrations of $B$ were observed in leaf tissues in 2015 and 2016, and to a lesser extent fruit tissues. Calcium remained unchanged regardless of treatment and tissue type. Under the conditions of this study, foliar applications of $\mathrm{Ca}$ and $\mathrm{B}$ did not lead to increased fruit set or yield. This research suggests that other approaches should be explored to increase fruit set and corresponding yields of highbush blueberry grown in northwest Washington.
\end{abstract}

Pollination deficits and subsequent low fruit set remain among the most important horticultural challenges to sustained yields of highbush blueberry in northwestern Washington (Washington Blueberry Commission, 2017). Washington State is a part of the Pacific Northwest (PNW), which is a major blueberry production region, contributing significantly to global production of both conventional and organic highbush blueberry. In 2016, Washington State was the nation's leading producer of blueberries with over 54.4 million $\mathrm{kg}$ of berries harvested from 5423 ha and a production value of about

\footnotetext{
Received for publication 20 June 2017. Accepted for publication 9 Aug. 2017.

This work was funded by the Washington Blueberry Commission.

We would like to acknowledge the assistance of our grower collaborators and Sean Watkinson, Rachel Rudolph, and Carter DeGraw for project assistance.

${ }^{1}$ Graduate Research Assistant.

${ }^{2}$ Assistant Professor.

${ }^{3}$ Corresponding author. E-mail: lisa.devetter@wsu. edu.
}

\$94 million (USDA, 2016). Blueberry growers in the $\mathrm{PNW}$ frequently apply $\mathrm{Ca}$ and B foliarly as annual applications for field maintenance and promotion of fruit set and crop yields. This practice is often done regardless of plant nutrient status and despite a lack of evidence supporting their regular use for this specific purpose. The goal of this project was to evaluate the impact of foliar applications of $\mathrm{Ca}$ and $\mathrm{B}$ and assess whether these practices should be recommended to promote fruit set and subsequent yields in highbush blueberry grown in the PNW.

Pollination and ovule fertilization in highbush blueberry normally occurs over a 5- to 12-d period on a per flower basis (Dogterom et al., 2000). Pollination may be constrained in this short time-period because of marginal weather conditions that reduce honeybee (Apis mellifera L.) activity (i.e., air temperature $<12{ }^{\circ} \mathrm{C}$, wind speed $>20 \mathrm{kph}$ ) and nutrient deficiencies (Tuell and Isaacs, 2010). Reproductive tissues (i.e., pollen, ovules, and developing embryos) are sensitive to nutrient concentrations in the flower and stem tissues (May and Killingbeck, 1992). Increased availability of nutrients involved in pollen tube elongation, plasma-membrane functioning, and other reproductive processes critical for fertilization and berry development, specifically $\mathrm{Ca}$ and $\mathrm{B}$, could potentially increase fruit set under conditions that are otherwise limiting (Kumar et al., 2016; Muengkaew et al., 2017).

Blueberry plants are calcifuges, requiring low soil $\mathrm{pH}$ and having generally efficient uptake of Ca relative to other temperate fruit crops (Taiz and Zeiger, 2002). Calcium movement and distribution within the blueberry plant varies by cultivar (Strik and Vance, 2015). Despite sufficient leaf $\mathrm{Ca}$ concentrations $(0.41 \%$ to $0.8 \% \mathrm{Ca}$; Hart et al., 2006), limited movement of $\mathrm{Ca}$ from leaf and stem tissues into developing reproductive tissues may lead to deficiencies, reducing fruit quality and, in some cultivars (e.g., 'Draper'), causing poor fruit development and premature fruit drop (Gerbrandt, 2015). Calcium mobility is often limited due to relatively low rates of fruit transpiration (2.5-3.0 mmol $\mathrm{CO}_{2} / \mathrm{kg} / \mathrm{h}$ ) compared with leaves, thereby limiting the movement of dissolved $\mathrm{Ca}$ in the xylem to fruit (Angeletti et al., 2010).

Calcium $(\mathrm{Ca})$ is involved in fruit abscission and pollen tube growth (Brewbaker and Kwack, 1963; Malho and Trewavas, 1996). Calcium deficiency can reduce the strength of the middle lamella and consequently make cells more prone to shearing, leading to fruit abscission (Glenn et al., 1988; Gough and Litke, 1980). Low Ca concentrations in the pollen of primrose (Primula officinalis L.) and butcher's broom (Ruscus aculeatus L.) have been correlated with reduced rates of pollen germination, with some dependence of germination on $\mathrm{Ca}$ levels found within the stigma (Bednarska, 1991; Brewbaker and Kwack, 1963; Taylor and Hepler, 1997). Calcium concentrations in the stigma and style may similarly impact the effectiveness of pollen germination and tube elongation, as suggested in studies in tobacco (Nicotinia tabacum L.) and Japanese pear (Pyrus pyrifolia L.) (Ge et al., 2009; Hiratsuka et al., 2002). To improve pollen viability and fruit set, $\mathrm{Ca}$ is often applied alone or mixed with other foliarapplied agrochemicals during bloom and throughout the growing season in highbush blueberry grown in the PNW. Growers also apply foliar $\mathrm{Ca}$ because preharvest applications may increase fruit firmness, an important attribute of quality for fresh fruit (Angeletti et al., 2010). Calcium is rarely soil applied in blueberry, in part because it has been shown to inconsistently affect leaf and fruit $\mathrm{Ca}$ levels and has had no effect on berry yield, size, or firmness based on studies conducted in Michigan (Hanson and Berkheimer, 2004). However, there is risk when applying commercial $\mathrm{Ca}$ containing foliar fertilizers, specifically for formulations that contain calcium chloride. High rates of calcium chloride can cause leaf phytotoxicity because of blueberry's sensitivity to the chloride ion, especially in young blueberry plants (Retamales and Arredondo, 1995). 
Table 1. Commercial calcium (Ca) and boron (B) foliar fertilizers applied to 'Bluecrop' and 'Draper' blueberry grown in northwest Washington in 2015 and 2016. Table lists treatment identification, year applied, product name, chemical formulation and form, rate, and concentration (in ppm).

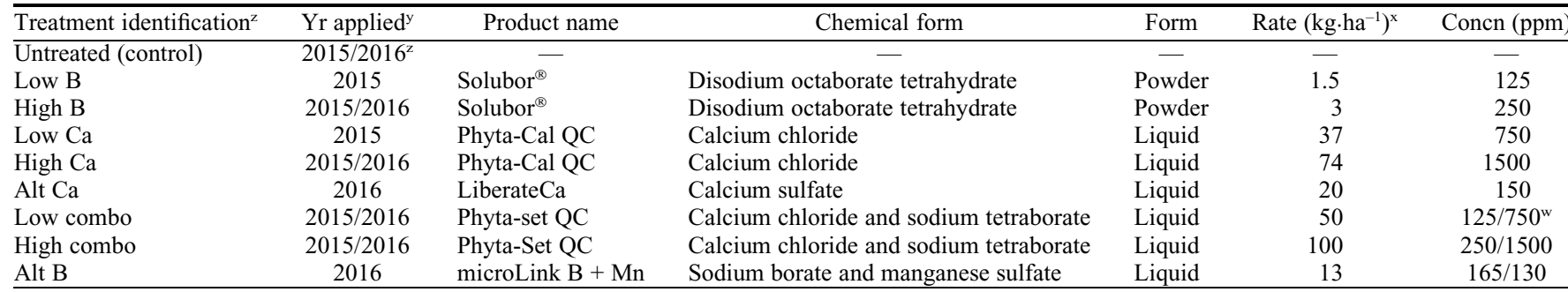

${ }^{\mathrm{z}}$ Treatments were applied according to manufacturer's recommendations from early pink bud to petal fall every $7-10 \mathrm{~d}$ for a total of six applications per year. ${ }^{\mathrm{y}}$ Low $\mathrm{Ca}$ and Low B treatments were removed in 2016 because of insignificant treatment effects and replaced with alternative (Alt) products, Alt Ca and Alt B; High Ca, High B, High. Combo (Ca + B) applied in both 2015 and 2016.

${ }^{\mathrm{x}}$ Application amount given as L.ha except for Low and High B which are $\mathrm{kg} \cdot \mathrm{ha}^{-1}$.

${ }^{\mathrm{w}}$ Concentration corresponds to the treatment, except for the combination treatment where B is listed before Ca and for the Alt B treatment, where B is listed first followed by Mn.

${ }^{\mathrm{v} S o l u b o r}{ }^{\circledR}$ is manufactured by Rio T into, Greenwood Village, CO. Phyta-Cal QC and Phyta-Set QC are manufactured by California Organic Fertilizers Inc., Fresno, CA. MicroLink B + Mn and LiberateCa are manufactured by AgroLiquid, St. Johns, MI.

Boron (B) is an important micronutrient for plant growth. In blueberries, B may be especially important for pollen germination and cell elongation (Retamales and Hancock, 2012). Boron is often deficient in blueberry production in western Washington and Oregon, and this is exacerbated by dry weather and heavy crop loads (Marshner, 1995). Boron in the soil reaches plant roots largely through mass flow; deficiency is common in soils with low organic matter, sandy/coarse texture, or both (Goldberg, 1997). The difference between sufficiency and toxicity of B is marginal in plants, including blueberry. Typically, B is not applied at concentrations higher than $500 \mathrm{ppm}$ in blueberry because of the risk of phytotoxicity (Hart et al., 2006). Although B is readily absorbed and mobile within the xylem of plants, making foliar applications during the dynamic growth phase, occurring during floral development, pollen germination, fertilization, and early berry development, may increase absorption and movement to targeted tissues (Brown and $\mathrm{Hu}, 1996$; Lord and Russell, 2002). This intense period of development is metabolically demanding, and plant nutrient levels at this stage may have far-reaching consequences on fruit set, berry weight, yield, and fruit composition at harvest to various degrees across cultivars. Annual applications of $\mathrm{B}$ are recommended in blueberry based on tissue nutrient analyses, but the justification and impact of these applications on promoting fruit set is largely unknown in the PNW region (Hart et al., 2006).

The application of $\mathrm{Ca}$ and $\mathrm{B}$ as foliar nutrients in early spring may improve pollen health and ovule fertilization, as well as fruit set, berry development, and subsequent berry yields. It is hypothesized that application of these nutrients during the dynamic growth stages of flower and fruit development, when these nutrients may be limiting, will be most effective at enhancing these variables associated with yield. Therefore, a trial was conducted with the objective to investigate whether foliar $\mathrm{Ca}$ and $\mathrm{B}$ applied from early pink bud to petal fall would increase fruit set, yield, and attributes of berry quality (size and firmness) in highbush blueberry grown in northwest Washington.

\section{Materials and Methods}

The experiment was conducted in 2015 and continued with slight alterations in 2016 in northwestern Washington. Four locations were used with two locations for the cultivar 'Bluecrop' (Skagit, WA; location 1: lat. $48^{\circ} 46^{\prime} \mathrm{N}$, long. $122^{\circ} 42^{\prime} \mathrm{W}$; location 2: lat. $48^{\circ} 55^{\prime} \mathrm{N}$, long. $122^{\circ} 38^{\prime} \mathrm{W}$ ) and two locations for the cultivar 'Draper' (Whatcom, WA; location 3: lat. $48^{\circ} 99^{\prime} \mathrm{N}$, long. $122^{\circ} 24^{\prime} \mathrm{W}$; location 4: lat. $48^{\circ} 97^{\prime} \mathrm{N}$, long. $122^{\circ} 43^{\prime} \mathrm{W}$ ). All locations were commercial farms of mature northern highbush blueberry managed with standard commercial practices (Strik et al., 1993). All sites had a history of $\mathrm{Ca}$ and $\mathrm{B}$ application, with both nutrients being applied across all sites the year prior. No additional $\mathrm{Ca}$ and $\mathrm{B}$ were applied to the treated plants throughout the duration of the study outside of the treatments described in this study. Rows were spaced $3.0 \mathrm{~m}$ apart with perennial grass in the alley. Plants were drip irrigated at all locations. All sites were conventionally grown except location 2, which was certified organic. Pollinators were placed in the field at $\approx 10 \%$ bloom and remained through petal fall. Pollinators were stocked at the industry recommended rate of $\approx 8$ hives/hectare. Soil series were location 1 (Skagit silt loam), location 2 (Field silt loam, protected), location 3 (Pangborn muck, drained), and location 4 (Sumas silt loam; USDA, 2017). All sites were grown in raised beds with douglas-fir (Pseudotsuga menziesii L.) sawdust mulch. Treatments were arranged in a randomized complete block design with four replicates of each experimental unit (plot) at each location (Table 1). Plots comprised five contiguous plants in a row, and the row was considered a block. Data were collected on the inner three plants per plot. Trial locations remained the same for the duration of the experiment.

Treatments were applied every 7-10 d from the early pink bud stage and continuing through petal fall for a total of six applications per year (Michigan State University Extension, 2016). Treatments applied were four commercially available $\mathrm{Ca}$ and $\mathrm{B}$ foliar products, which were evaluated at each location. All products were applied within label rates and according to the manufacturer's instructions. Nine treatments were applied in 2015 and 2016 (Table 1). In 2016, the Low $\mathrm{Ca}$ and Low B treatments were dropped because of a lack of treatment effects and limited plot space for additional treatments of interest to be evaluated with grower cooperators. The high-rate treatments were maintained, and alternative $\mathrm{Ca}$ and $\mathrm{B}$ products were added based on grower cooperator interest. New treatments included in 2016 were referred to as "Alt B" and "Alt Ca," respectively (Table 1). New treatments were not applied at location 2 (certified organic site). Alt $\mathrm{Ca}$ was applied at the same timing as other applications, but was applied to the soil surface rather than to the leaves (as directed on the label). Treatment solutions were mixed in accordance with manufacturer's labels and did not include a surfactant. All products were liquid formulations with the exception of Low and High B, which were dry flowables, mixed with distilled water. Treatment applications were applied to drip with a hand sprayer (Model 1401P; Flo Master, Lowell, MI) in accordance with the product labels.

Soil samples were collected before treatment application in the first week of Mar. 2015 and during the last week of Sept. 2016. Soil samples were collected to evaluate the location conditions and to determine if soil nutrients differed within a site. Two cores were taken from each side of the raised bed per plot, and samples were pooled by block within sites. Samples consisted of a 7-cmdiameter core taken from the raised beds between plants and within the drip line irrigation zone to a depth of $15.5 \mathrm{~cm}$ after removing the mulch material from the surface of the raised bed. In the final week of July of both years, leaf tissue samples were collected from the most recent fully expanded leaves. Five leaves were collected per plant from the inner three plants per plot. 
Replications were pooled within each location. Samples were collected and prepared in accordance to Hart et al. (2006). Collected leaf samples were analyzed for microand macronutrients (Brookside Laboratories, New Bremen, OH). Nitrogen concentration was determined using a combustion analyzer (Model CNS-2000; LECO Corp., St. Joseph, $\mathrm{MI}$ ), whereas $\mathrm{Ca}$ and $\mathrm{B}$ were measured using a plasma optical emission spectrometer (Optima 3000DV; Perkin Elmer, Wellesley, MA) after microwave digestion in $70 \%(\mathrm{v} / \mathrm{v})$ nitric acid (Gavlak et al., 2003).

Before fruit set, the total number of canes per plant within each plot was counted. Two mature canes per plant were randomly selected, and all developing flower/fruit clusters on those canes were counted. Two clusters, the third from the shoot apex, on each of the selected canes were marked with flagging tape, and individual flowers were counted (four laterals per bush). In 2015, full bloom occurred during the third and fourth weeks of April in 'Bluecrop' and the first and second weeks of May for 'Draper'. In 2016, full bloom occurred in the first and second weeks of May for 'Bluecrop' and the second and third weeks of May for 'Draper'. About 20 d after petal fall, flagged clusters were reevaluated, and berries per cluster were counted to determine fruit set. The average berry number per bush was estimated for the inner three plants per plot using the equation: berry number per bush $=$ (cane number per bush) $\times$ (number fruit clusters per cane) $\times$ (average berry number per cluster) (DeVetter et al., 2016). Note that the number of fruiting clusters per cane was determined from two randomly selected canes per bush and average berry number per cluster was determined by taking the average of two randomly selected clusters for one cane. Yield per bush was subsequently estimated by using the following formula: estimated yield $=($ berry number per bush $) \times($ average berry weight $)$. At fruit maturity and before commercial harvest (the first and second weeks of July for both years in 'Bluecrop' and 'Draper', respectively), fruit samples ( $n=30$ per plot) were collected to determine average berry weight. A subsample ( $n=20$ per plot) of harvested berries was measured for firmness (FirmTech II machine; BioWorks Inc., Wamego, KS). The FirmTech equipment was set up with maximum and minimum compression forces of $200 \mathrm{~g}(1.96 \mathrm{~N})$ and $15 \mathrm{~g}(0.15 \mathrm{~N})$, respectively. Piston speed was configured to $6 \mathrm{~mm} \cdot \mathrm{s}^{-1}$ (Ehlenfeldt and Martin, 2002; Saftner et al., 2008). After weight and firmness measurements, sampled fruit were analyzed for micro- and macronutrients as described earlier for leaf tissue nutrients.

Air temperature, precipitation, and solar radiation were measured at $15 \mathrm{~min}$ increments for the experimental observation periods (1 Mar. through 31 May) by Washington State University AgWeatherNet (WSU AgWeatherNet, 2017; data provided courtesy of WSU AgWeatherNet and are copyright of WSU). Weather station sites were no more than $3.2 \mathrm{~km}$ from the experiment locations.
Data were analyzed using Ime4 (CRAN package R-studio) for a randomized block design. The overall effects of location, year, and cultivar were analyzed with $\mathrm{Cor}$ and $\mathrm{Cov}$ functions in R-studio for the five treatments applied in 2015 and 2016 (Table 1). Mean separations were performed with Tukey's honestly significant difference test (AGRICOLE package R-studio). Data were presented by year and cultivar because of significant year and cultivar effects. After accounting for cultivar effects, there was no significant effect of location (site). The effects of cultivar and year on measured variables were also analyzed using a two-way analysis of variance. Weather data were not subjected to statistical analysis and are presented as numerical mean comparisons by cultivar and year, as cultivars were grown in separate counties (Table 4). Soil data were likewise not statistically analyzed but were used to determine if variation in soil nutrient levels were present in the study. All statistical analysis was carried out in R-studio statistical platform, using the "cran" and "agricolae," and "ggplot" statistical packages (de Mendiburu, 2014; RStudio Team, 2015; Wickham, 2009).

\section{Results}

Soil, leaf, and fruit nutrients. Targeted $\mathrm{Ca}$ applications did not lead to significant differences in Ca concentrations in leaf tissue. Leaf B concentrations in High B-treated plots were increased significantly compared with the control ( $\approx 54 \%$ for 'Draper' and $\approx 37 \%$ for 'Bluecrop') in 2015 (Table 2). In 2016, leaf $\mathrm{B}$ concentrations in plants treated with High B were significantly increased compared with the control in 'Draper' $(\approx 49 \%$ increase), but not 'Bluecrop'. The Alt B treatment statistically increased leaf B concentrations in both 'Draper' and 'Bluecrop' plants in 2016 (50\% and 41\%, respectively). The $\mathrm{Ca}$ and $\mathrm{B}$ concentrations of ripe berries collected $\approx 3 \mathrm{~d}$ before commercial harvest were not significantly different regardless of the cultivar or applied treatments in 2015 and 2016. The soil nutrient composition within and across sites did not differ significantly at either sampling date (data not shown).

Fruit set, estimated yield, and berry weight and firmness. Fruit set was relatively low in both years of the study averaging $85 \%$ in the untreated plots. In 2016, we observed $\approx 14 \%$ lower fruit set across all locations than in 2015, with the average fruit set of 'Bluecrop' fields $\approx 22 \%$ lower in 2016 than 2015 and $\approx 5.5 \%$ lower in 'Draper' fields between the same years. There were no significant differences in fruit set of treated plots compared with the untreated control (Table 3). Similarly, there were no significant differences in estimated yield of treated plants compared with the untreated control (Table 3 ). Berry weight and fruit firmness were the same across treatments (Table 3; data not shown for firmness).

Weather conditions. Data taken between 1 Mar. and 31 May 2015 and 2016 indicated that the two geographic areas and pollination periods differed with respect to temperature, precipitation, and solar radiation (data not shown). The full bloom period for 'Bluecrop' was the third and fourth weeks of April in 2015 and the first and second weeks of May in 2016; the full bloom period for 'Draper' was first and second weeks of May in 2015 and second and third weeks of May in 2016, respectively (Table 4). The average daytime temperature during the pollination period in western Washington in 2015 was $2.5{ }^{\circ} \mathrm{C}$ higher than 2016 (Table 4). The bloom date

Table 2. Leaf and fruit tissue nutrient concentrations in highbush blueberry grown in northwest Washington in 2015 and 2016 after treatment with commercial calcium (Ca) and boron (B) fertilizers. Results show analyses based on dry weights for leaf samples collected late July and whole harvested fruit in 2015 and $2016(n=20$ per site with two sites per cultivar).

\begin{tabular}{|c|c|c|c|c|c|c|c|c|}
\hline & \multicolumn{4}{|c|}{ Bluecrop } & \multicolumn{4}{|c|}{ Draper } \\
\hline & \multicolumn{2}{|c|}{ Leaf } & \multicolumn{2}{|c|}{ Leaf } & \multicolumn{2}{|c|}{ Leaf } & \multicolumn{2}{|c|}{ Fruit } \\
\hline & $\mathrm{Ca}(\%)$ & B (ppm) & $\mathrm{Ca}(\%)$ & B (ppm) & $\mathrm{Ca}(\%)$ & B (ppm) & $\mathrm{Ca}(\%)$ & $\mathrm{B}(\mathrm{ppm})$ \\
\hline \multicolumn{9}{|l|}{2015} \\
\hline Untreated (control) & 0.57 & $476 \mathrm{a}^{\mathrm{z}}$ & 0.05 & 7.5 & 0.76 & $38.9 \mathrm{a}$ & 0.05 & 8.0 \\
\hline Low $B^{y}$ & 0.61 & $59.6 \mathrm{ab}$ & 0.05 & 9.3 & 0.81 & $55.5 \mathrm{ab}$ & 0.05 & 12.6 \\
\hline High B & 0.63 & $75.7 \mathrm{~b}$ & 0.04 & 13.7 & 0.85 & $84.2 \mathrm{~b}$ & 0.06 & 15.7 \\
\hline Low $\mathrm{Ca}$ & 0.60 & $48.6 \mathrm{a}$ & 0.06 & 11.3 & 0.82 & $38.5 \mathrm{a}$ & 0.05 & 8.9 \\
\hline High Ca & 0.62 & $60.8 \mathrm{ab}$ & 0.04 & 9.5 & 0.80 & $39.8 \mathrm{a}$ & 0.05 & 12.3 \\
\hline Low combo & 0.57 & $62.8 \mathrm{a}$ & 0.04 & 6.9 & 0.81 & $38.6 \mathrm{a}$ & 0.04 & 8.1 \\
\hline High combo & 0.62 & $69.5 \mathrm{ab}$ & 0.05 & 8.2 & 0.78 & $36.6 \mathrm{a}$ & 0.05 & 10.4 \\
\hline$P$ value & $\mathrm{NS}^{\mathrm{x}}$ & 0.0175 & NS & NS & NS & 0.0306 & NS & NS \\
\hline \multicolumn{9}{|l|}{$2016^{\mathrm{w}}$} \\
\hline Untreated (control) & 0.64 & $55.1 \mathrm{a}$ & 0.05 & 10.2 & 0.75 & $43.7 \mathrm{a}$ & 0.04 & 10.0 \\
\hline High B & 0.69 & $63.5 \mathrm{ab}$ & 0.04 & 14.3 & 0.84 & $85.7 \mathrm{~b}$ & 0.04 & 11.5 \\
\hline Alt B & 0.64 & $93.1 \mathrm{~b}$ & 0.05 & 16.7 & 0.75 & $87.3 \mathrm{~b}$ & 0.05 & 11.7 \\
\hline High Ca & 0.72 & $46.1 \mathrm{a}$ & 0.05 & 9.8 & 0.77 & $44.6 \mathrm{a}$ & 0.05 & 8.3 \\
\hline Alt $\mathrm{Ca}$ & 0.80 & $52.7 \mathrm{a}$ & 0.05 & 13.5 & 0.86 & $43.8 \mathrm{a}$ & 0.05 & 10.2 \\
\hline High combo & 0.67 & $63.1 \mathrm{ab}$ & 0.04 & 14.8 & 0.74 & $47.2 \mathrm{a}$ & 0.04 & 12.3 \\
\hline$P$ value & NS & 0.0272 & NS & NS & NS & 0.0372 & NS & NS \\
\hline
\end{tabular}

${ }^{\mathrm{z}}$ Letters of difference, with the same letters within a column denoting not significant at $\alpha=0.05$.

${ }^{\mathrm{y}}$ Indicates Low and High concentration of treatments.

${ }^{\mathrm{x}}$ Indicates no significant difference (Ns) at $\alpha=0.05$.

${ }^{\text {w }}$ Treatment changes in 2016 included removal of Low Ca and Low B treatments and the addition of Alt B and Alt $\mathrm{Ca}$. 
Table 3. Fruit set ( $n=20$ per site with two sites per cultivar), estimated yield ( $n=12$ plants per site with two sites per cultivar), and fruit weight ( $n=30$ per site with two sites per cultivar) of 'Bluecrop' and 'Draper' blueberry after treatment with commercial calcium (Ca) and boron (B) foliar fertilizers in northwest Washington in 2015 and 2016.

\begin{tabular}{|c|c|c|c|c|c|c|}
\hline & \multicolumn{2}{|c|}{ Fruit set $(\%)^{z}$} & \multicolumn{2}{|c|}{ Estimated yield $(\mathrm{kg} / \mathrm{plant})^{\mathrm{y}}$} & \multicolumn{2}{|c|}{ Fruit wt $\left(\mathrm{g} /\right.$ fruit) ${ }^{\mathrm{x}}$} \\
\hline & Bluecrop & Draper & Bluecrop & Draper & Bluecrop & Draper \\
\hline \multicolumn{7}{|l|}{$\overline{2015}$} \\
\hline Control & 87 & 88 & 3.5 & 4.2 & 1.99 & 2.09 \\
\hline Low B & 88 & 76 & 4.0 & 3.6 & 2.08 & 2.12 \\
\hline High B & 82 & 79 & 3.4 & 3.4 & 2.00 & 2.17 \\
\hline Low $\mathrm{Ca}$ & 86 & 80 & 3.8 & 3.7 & 1.96 & 2.17 \\
\hline High Ca & 83 & 87 & 4.1 & 3.5 & 2.04 & 2.07 \\
\hline Low combo & 98 & 86 & 3.4 & 3.7 & 1.93 & 2.02 \\
\hline High combo & 95 & 88 & 4.1 & 4.0 & 1.94 & 2.06 \\
\hline$P$ value & $\mathrm{NS}^{\mathrm{w}}$ & NS & NS & NS & NS & NS \\
\hline \multicolumn{7}{|l|}{$2016^{v}$} \\
\hline Untreated & 65 & 82 & 2.8 & 5.9 & 1.93 & 3.12 \\
\hline High B & 64 & 78 & 2.7 & 6.3 & 1.97 & 2.98 \\
\hline Alt B & 62 & 78 & 2.6 & 7.2 & 2.09 & 3.08 \\
\hline High $\mathrm{Ca}$ & 61 & 80 & 2.5 & 7.0 & 2.01 & 2.90 \\
\hline Alt Ca & 66 & 85 & 2.2 & 6.2 & 2.12 & 2.73 \\
\hline Low combo & 78 & 75 & 2.9 & 6.1 & 2.10 & 2.71 \\
\hline High combo & 68 & 83 & 3.3 & 5.9 & 2.11 & 2.83 \\
\hline$P$ value & NS & NS & NS & NS & NS & NS \\
\hline
\end{tabular}

${ }^{\mathrm{z}}$ Fruit set determined from the third distal cluster on four laterals per bush per treatment and replicate.

${ }^{\mathrm{y}}$ Estimated yield is presented on a per plant basis and was determined by multiplying the total cane number per plant by the average fruiting cluster number per cane (determined from two canes per plant) by the average berry number per cluster (determined from four clusters per plant) the by average berry weight per treatment.

${ }^{\mathrm{x}}$ Average berry weight determined from 30 berry samples per plot.

${ }^{\mathrm{w}}$ Indicates no significant difference (NS) at $\alpha=0.05$.

${ }^{\mathrm{v}}$ Treatment changes in 2016 included removal of Low Ca and Low B treatments and the addition of Alt B and Alt Ca.

Table 4. Average air daytime temperature, cumulative precipitation, and average solar radiation for the full bloom periods of 'Bluecrop' and 'Draper' blueberry grown in Skagit and Whatcom counties, WA, respectively.

\begin{tabular}{lccccc}
\hline & \multicolumn{2}{c}{2015} & & 2016 \\
\cline { 2 - 5 } & Bluecrop $^{\mathrm{z}}$ & Draper & & Bluecrop & Draper \\
\hline Air temperature $\left({ }^{\circ} \mathrm{C}\right)^{\mathrm{y}}$ & 14.5 & 16.4 & 10.8 & 14.74 \\
Total precipitation $(\mathrm{mm})$ & 10 & 8 & 28 & 11 \\
Solar radiation $\left(\mathrm{W} / \mathrm{m}^{2}\right)$ & 356.8 & 367.0 & 259.3 & 344.3 \\
\hline
\end{tabular}

z'Bluecrop' was cultivated in Skagit County, whereas 'Draper' was cultivated in Whatcom County. The full bloom period for 'Bluecrop' was the third and fourth weeks of April in 2015 and the first and second weeks of May in 2016; the full bloom period for 'Draper' was first and second weeks of May in 2015 and second and third weeks of May in 2016, respectively.

${ }^{\mathrm{y}}$ Weather data were collected every $15 \mathrm{~min}$ and are presented by cultivar pollination period; data are provided courtesy of WSU AgWeatherNet and are copyright of WSU.

was $\approx 2$ weeks earlier in 2016 than 2015, though the harvest dates were the same. Precipitation differed by $\approx 1 \mathrm{~cm}$ with more precipitation in the timeframe between March to May of 2016 than 2015. Total precipitation during the pollination period was 42 and $65 \mathrm{~mm}$ in 2015 and 2016, respectively. Solar radiation from 1 Mar. to 31 May was greater in 2015 in western Washington, averaging $218 \mathrm{~W} / \mathrm{m}^{2}$ compared with $183 \mathrm{~W} / \mathrm{m}^{2}$ in 2016 . These environmental variables demonstrate the differences in weather conditions between 2015 and 2016 .

\section{Discussion}

The goal of this study was to evaluate the effect of foliar applications of $\mathrm{Ca}$ and $\mathrm{B}$ on fruit set, yield and the fruit quality characteristics of berry size and firmness. Under the conditions of our study, foliar applications of $\mathrm{Ca}$ and $\mathrm{B}$, either alone or in combination, did not improve fruit set, yield, or our measured of $\mathrm{Ca}$ because of cultivar genetics that impact $\mathrm{Ca}$ uptake and partitioning in the plant.

The application rates may have been insufficient to increase $\mathrm{Ca}$ concentrations in fruit. Increased rates of Ca may be necessary to overcome the immobility of $\mathrm{Ca}$ in the leaf (Biddulph et al., 1959). Studies have shown that foliar $\mathrm{Ca}$ applications must penetrate the leaf cuticle or the uptake will be limited (Schlegel and Schönherr, 2001). Caution is necessary if evaluating higher application rates, as chloride-containing calcium products can cause phytotoxicity. Although we followed label recommendations and did not use a surfactant when applying treatments, $\mathrm{Ca}$ uptake may have been improved had we mixed the product with a surfactant. The addition of a surfactant would have reduced the surface tension of spray droplets and may have improved penetration across the cuticle and into leaf or floral tissues (Harker and Ferguson, 1991; Hess and Foy, 2000).

It is also possible that the $\mathrm{Ca}$ application timing may not have been aligned with the optimal plant uptake through foliage. We applied $\mathrm{Ca}$ during bloom through petal fall intending to optimize $\mathrm{Ca}$ availability during pollination and fertilization, targeting rapidly developing floral and fruit tissues. Therefore, leaves were not fully expanded and mature at the time of application. This application timing also aligns with grower practices, allowing us to test the efficacy of this practice. In addition, applying $\mathrm{Ca}$ during Phase I of berry development (rapid cell division), when $\mathrm{Ca}$ is more readily absorbed into young fruit from the transpirational stream, may more effectively increase $\mathrm{Ca}$ concentrations in leaves and fruits (Biddulph et al., 1959; Milthorpe and Moorby, 1969). The results of this study support those of Vance et al. (2017), who found foliar $\mathrm{Ca}$ applications did not increase leaf or fruit $\mathrm{Ca}$ concentrations and had no impact on fruit quality and shelf life in blueberry and other small fruit crops [blackberry (Rubus L. subgenus Rubus), strawberry (Fragaria ×ananassa), and red raspberry (Rubus idaeus)] grown in Oregon. The investigators in this study targeted applications to the later phases of fruit development, with $\mathrm{Ca}$ applications starting at the early green fruit stage and were repeated three or four times per year.

We used foliar-applied B timed with the presence of flowers to determine if pollen health and germination could be improved, as would be evidenced by increased fruit set and possibly berry size. Because of a lack of a treatment effect between the Low and High B treatments, the Low B treatment was removed in 2016. The ineffectiveness of the Low B treatment and the slight increase in tissue $\mathrm{B}$ concentrations realized by the higher application rates of the same product lead us to feel justified in this treatment adjustment. Leaf B concentrations were within the accepted range of 41-80 ppm for 2015 and 2016 in 'Bluecrop' (Hart et al., 2006). However, leaf B concentrations in 'Draper' were in excess of the sufficiency standards for 
High and Alt B treatments in both 2015 and 2016. Phytotoxicity risk with foliar B is mentioned in the literature for a variety of small fruit crops (Chang et al., 2004; Cheour et al., 1990; Morris et al., 1980; Retamales and Arredondo, 1995); however, no phytotoxicity damage was observed in our study.

The only significant difference in leaf B was seen in plants treated with High B and Alt $\mathrm{B}$, with Alt $\mathrm{B}$ also having manganese in its formulation (Mn; Table 1). Manganese was added to the mixture because studies have suggested B uptake may be improved with the addition of Mn (Fageria, 2001; Henderson and Veal, 1948). The Alt B treatment supplied $165 \mathrm{ppm}$ of $\mathrm{B}$ compared with the $250 \mathrm{ppm}$ of $\mathrm{B}$ in the High $\mathrm{B}$ treatment, but both resulted in a similar increase in leaf B concentration. This suggests the Mn may have improved the uptake of B and required less overall $\mathrm{B}$ for the same result. The use of $\mathrm{Mn}$ in conjunction with $\mathrm{B}$ to lower the overall concentration of $\mathrm{B}$ applied while still maintaining the efficacy of a higher rate, as used in studies with 'Draper' green fruit drop (discussed below; Gerbrandt, personal communication), may be beneficial in avoiding rates of $B$ that could cause phytotoxicity. Despite differences in leaf tissue $\mathrm{B}$ concentrations, no effect was observed for fruit set, yield, berry size, or firmness. While leaf and fruit B concentrations were not of main concern, it is interesting that despite elevated leaf $\mathrm{B}$ concentrations in the High B and Alt B treatments, an increase in $\mathrm{B}$ in fruit tissues was not observed. The mobility of B in plants has been shown to be species dependent, and our study suggests B mobility from leaf to flower/fruit tissues may be limited in highbush blueberry (Brown and $\mathrm{Hu}, 1996$; Brown and Shelp, 1997).

The lack of fruit set improvement is not surprising given that fruit $\mathrm{Ca}$ and $\mathrm{B}$ concentrations did not change even when leaf nutrient concentrations were increased. As stated earlier, regardless of treatment, elevated leaf $B$ concentrations did not lead to elevated fruit $\mathrm{B}$ concentrations or correlate with fruit set and berry weight improvements, which would have been expected if pollination and fertilization were improved. Thus, any anticipated benefits to reproductive organs or mature berries would be unlikely to occur. Likewise, the absence of increased leaf and fruit $\mathrm{Ca}$ concentrations made $\mathrm{Ca}$ treatment effects in fruit set, berry size, and firmness unlikely. Calcium in other fruits, such as apples (Malus domestica), has been shown to enter fruit while young and transpiring, possibly due to an increased stomatal number or function during the first weeks of fruit growth and development (Schlegel and Schönherr, 2002; Wilkinson, 1968). Targeting the dynamic growth phase during early bloom and fruit set did not appear to sufficiently increase fruit nutrient levels in blueberry, and this may be due to a reduced number or function of stomata in early fruit development; stomatal function in blueberry leaves and fruit are not fully understood
(Vance et al., 2017). Sufficient Ca may not have been applied after fruit set and during the initial phases of berry development to observe an effect. In addition, spray applications in a commercial setting are typically applied with air blast sprayers; however, because of the size and set up of this experiment a hand sprayer was used. The difference in coverage and droplet size between these two methods of application may have impacted the efficiency and uptake of nutrients.

Premature drop of green fruit before harvest, commonly referred to as "Draper drop," impacted yield of 'Draper' plants in 2016 (there was no perceivable drop in 2015). This yield loss due to fruit drop is not reflected in the yield increase from 2015 to 2016, which is likely due to differences in percentage fruit set between years. The lack of 'Draper' fruit drop in 2015 may have been due to environmental effects, as the spring/ summer of the 2015 season was warmer and dryer ( $3 \%$ and $19 \%$, respectively) with more solar radiation than 2016 (Table 4); it has been anecdotally observed that fruit drop in 'Draper' is exacerbated by cool and overcast conditions during early fruit development (Gerbrandt, personal communication).

In addition to cultivar specific fruit drop, there is a strong positive relationship between warmer, drier weather conditions and foraging of honeybees, the primary pollinator of highbush blueberry (Seeley 2009; Tuell and Isaacs, 2010). Fruit set in 'Bluecrop' was reduced in 2016, potentially because of the effect of low air temperatures during bloom, which may have reduced the foraging activity of pollinators, leading to reduced pollination, fertilization and fruit set. The weather conditions in 2016 were more typical (compared with 2015) for northwest Washington, with lower air-temperatures and more accumulated precipitation (Table 4). Lower daytime air temperature $\left(\approx 12{ }^{\circ} \mathrm{C}\right)$ and increased precipitation, common to the northwest spring, occurred across multiple days through the bloom period of 'Bluecrop' plants in 2016. The difference in fruit set between 'Bluecrop' and 'Draper' in 2016 is likely explained by weather during bloom and floral morphology. 'Draper' blooms later in the calendar year than 'Bluecrop' and 'Draper' flowers tend to have a larger and more spherical corolla than 'Bluecrop' flowers, which may enable more effective honeybee pollination (Courcelles et al., 2013). The offset of bloom time between 'Draper' and 'Bluecrop' meant that the 'Draper' bloom condition in 2016 was much warmer and drier $\left(\approx 15{ }^{\circ} \mathrm{C}\right.$ for 'Bluecrop' and $24^{\circ} \mathrm{C}$ for 'Draper') in the $1-2$ weeks after 'Bluecrop' bloom.

\section{Conclusion}

Calcium and B applications did not improve fruit set, estimated yield, berry weight, or fruit firmness in 'Bluecrop' or 'Draper' plants under the conditions of this study. Therefore, we conclude that similar applications are unlikely to improve these measured aspects of blueberry fruit production in other cultivars grown in the PNW. This information is applicable to commercial growers in the PNW who regularly apply these products during the developmental stages under investigation as we found no evidence justifying their use. We suggest that increased product rates, alternative $\mathrm{Ca}$ and $\mathrm{B}$ forms and formulations with other nutrients, use of surfactants, and modified timings be tested in effort to increase $\mathrm{Ca}$ and $\mathrm{B}$ concentrations in reproductive tissues of blueberry and possibly lead to improved fruit set and yield for a region that chronically experiences low fruit set.

\section{Literature Cited}

Angeletti, P., H. Castagnasso, E. Miceli, L. Terminiello, A. Concellón, A. Chaves, and A. Vicente. 2010 Effect of preharvest calcium applications on postharvest quality, softening and cell wall degradation of two blueberry (Vaccinium corymbosum) varieties. Postharvest Biol. Technol. 58:98-103.

Bednarska, E. 1991. Calcium uptake from the stigma by germinating pollen in Primula officinalis L. and Ruscus aculeatus L. Sex. Plant Reprod. 4:36-38.

Biddulph, O., R. Cory, and S. Biddulph. 1959. Translocation of calcium in the bean plant. Plant Physiol. 34:512-519.

Brewbaker, J.L. and B.H. Kwack. 1963. The essential role of calcium ion in pollen germination and pollen tube growth. Amer. J. Bot. 50:859-865.

Brown, H. and B. Shelp. 1997. Boron mobility in plants. Plant Soil 193:85-101.

Brown, P. and H. Hu. 1996. Phloem mobility of boron is species dependent: Evidence for phloem mobility in sorbitol-rich species. Ann. Bot. (Lond.) 77:497-506.

Chang, Y.C., K. Grace-Martin, and W.B. Miller. 2004. Efficacy of exogenous calcium application for reducing upper leaf necrosis in Lilium 'Star Gazer'. HortScience 39:272-275.

Cheour, F., C. Willemont, J. Arul, Y. Desjardins, J. Makhlouf, P.M. Charest, and A. Gosselin. 1990. Foliar application of calcium chloride delays postharvest ripening of strawberry. J. Amer. Soc. Hort. Sci. 115:789-792.

Courcelles, D.M.M., L. Button, and E. Elle. 2013 Bee visit rates vary with floral morphology among highbush blueberry cultivars ( Vaccinium corymbosum L.). J. Appl. Entomol. 137:693-701.

DeVetter, L.W., S. Watkinson, R. Sagili, and T. Lawrence. 2016. Honey bee activity in northern highbush blueberry differs across growing regions in Washington state. HortScience 51:1228-1232.

Dogterom, M.H., M.L. Winston, and A. Mukai. 2000. Effect of pollen load size and source (self, outcross) on seed and fruit production in highbush blueberry cv. 'Bluecrop' (Vaccinium corymbosum; Ericaceae). Amer. J. Bot. 87:1584-1591

Ehlenfeldt, M.K. and R.B. Martin. 2002. A survey of fruit firmness in highbush blueberry and species-introgressed blueberry cultivars. HortScience 37:386-389.

Fageria, V.D. 2001. Nutrient interactions in crop plants. J. Plant Nutr. 24:1269-1290.

Gavlak, R., D. Horneck, R.O. Miller, and J. Kotuby-Amacher. 2003. Soil, plant and water reference methods for the western region. WCC-103 publication. WREP 125:17-36. 
Ge, L.L., C.T. Xie, H.Q. Tian, and S.D. Russell. 2009. Distribution of calcium in the stigma and style of tobacco during pollen germination and tube elongation. Sex. Plant Reprod. 22:87-96.

Gerbrandt, E. 2015. What causes green fruit drop and can we prevent it? Horticulture Growers' Short Course. Lower Mainland Hort. Improvement Assn. Pacific Ag. Show Proc., 57th.

Glenn, G.M., A.S.N. Reddy, and B.W. Poovaiah. 1988. Effect of calcium on cell wall structure, protein phosphorylation and protein profile in senescing apples. Plant Cell Physiol. 29:565572 .

Goldberg, S. 1997. Reactions of boron with soils. Plant Soil 193:35-48.

Gough, R.E. and W. Litke. 1980. An anatomical and morphological study of abscission in highbush blueberry fruit. J. Amer. Soc. Hort. Sci. 105:335-341.

Hanson, E.J. and S.F. Berkheimer. 2004. Effect of soil calcium applications on blueberry yield and quality. Small Fruits Rev. 3:133-139.

Harker, F.R. and I.B. Ferguson. 1991. Effects of surfactants on calcium penetration of cuticles isolated from apple fruit. Sci. Hort. 46:225233.

Hart, J.M., B. Strik, L. White, and W. Yang. 2006. Nutrient management for blueberries in Oregon. Oregon State University Extension Service. EM 8918.

Henderson, H. and P. Veal. 1948. The effect of the interrelationship of boron and manganese on the growth and calcium uptake of blue lupine (Lupinus angustifolius L.) in solution culture. Plant Physiol. 23:609-620.

Hess, D. and L. Foy. 2000. Interaction of surfactants with plant cuticles 1 . Weed Technol. 14:807-813.

Hiratsuka, S., M. Watanabe, Y. Kawai, T. Maejima, K. Kawamura, and Y. Katoh. 2002. Action mode of calcium formate as a chemical thinner on Japanese pear flower. J. Jpn. Soc. Hort. Sci. 71:62-67.

Kumar, J., R. Kumar, R. Rai, D. Shankar Mishra, S. Kumar Singh, and P. Kisan Nimbolkar. 2016. Influence of foliar application of mineral nutrients at different growth stages of guava. J. Plant Nutr. 40:656-661.
Lord, E.M. and S.D. Russell. 2002. The mechanisms of pollination and fertilization in plants. Annu. Rev. Cell Dev. Biol. 18:81-105.

Malho, R. and A.J. Trewavas. 1996. Localized apical increases of cytosolic free calcium control pollen tube orientation. Plant Cell 8:19351949.

Marshner, H. 1995. Mineral nutrition of higher plants. Academic Press, New York, NY.

May, J.D. and K.T. Killingbeck. 1992. Effects of preventing nutrient resorption on plant fitness and foliar nutrient dynamics. Ecol. 73:18681878.

de Mendiburu, F. 2014. Statistical procedures for agricultural research. National Engineering University, Lima Peru, MS Thesis.

Michigan State University Extension (MSU Extension). 2016. Blueberry growth stages table. 2 Feb. 2017. <http://msue.anr.msu.edu/topic/blueberries/ growing_blueberries/growth_stages_table $>$.

Milthorpe, L. and J. Moorby. 1969. Vascular transport and its significance in plant growth. Annu. Rev. Plant Physiol. 20:117-138.

Morris, J.R., D.L. Cawthon, G.S. Nelson, and P.E. Cooper. 1980. Effects of postharvest calcium sprays and postharvest holding on firmness and quality of machine-harvested blackberries. HortScience 15:33-34.

Muengkaew, R., P. Chaiprasart, and P. Wongsawad. 2017. Calcium-boron addition promotes pollen germination and fruit set of mango. Intl. J. Fruit Sci. 17:147-158.

Retamales, J.B. and C.A. Arredondo. 1995. Calcium and fruit firmness in highbush blueberry: Natural gradients and the effect of foliar applications. HortScience 30:784.

Retamales, J.B. and J.F. Hancock. 2012. Blueberries. Vol. 21. Cabi, New York, NY.

RStudio Team. 2015. RStudio: Integrated development for R. RStudio, Inc., Boston, MA. $<$ http://www.rstudio.com>.

Saftner, R., J. Polashock, M. Ehlenfeldt, and B. Vinyard. 2008. Instrumental and sensory quality characteristics of blueberry fruit from twelve cultivars. Postharvest Biol. Technol. 49:19-26.

Schlegel, K. and J. Schönherr. 2001. Selective permeability of cuticles over stomata and trichomes to calcium chloride. Intl. Symp. Foliar Nutr. Perennial Fruit Plants594:91-96.

Schlegel, K. and J. Schönherr. 2002. Stage if development affects penetration of calcium chloride into apple fruits. J. Plant Nutr. Soil Sci. 165:738-745.

Seeley, T.D. 2009. The wisdom of the hive: The social physiology of honey bee colonies. Harvard Univ. Press, Boston, MA.

Strik, B.C. and A.J. Vance. 2015. Seasonal variation in leaf nutrient concentration of northern highbush blueberry cultivars grown in conventional and organic production systems. HortScience 50:1453-1466.

Strik, B., C. Brun, M. Ahmedullah, A. Antonelli, L. Askham, D. Barney, and D. Havens. 1993. Highbush blueberry production. PNW 215 (USA).

Taiz, L. and E. Zeiger. 2002. Plant physiology. 5th ed. Sinauer Associates, Sunderland, MA.

Taylor, L.P. and P.K. Hepler. 1997. Pollen germination and tube growth. Annu. Rev. Plant Biol. 48:461-491.

Tuell, J.K. and R. Isaacs. 2010. Weather during bloom affects pollination and yield of highbush blueberry. J. Econ. Ent. 103:557-562.

United States Department of Agriculture (USDA). 2016. Noncitrus fruits and nuts 2016 summary. 27 June 2017. <http://usda.mannlib. cornell.edu/usda/nass/NoncFruiNu//2010s/ 2016/NoncFruiNu-07-27-2016.pdf >.

United States Department of Agriculture (USDA). 2017. Web soil survey. 10 Jan. 2017. http:// websoilsurvey.nrcs.usda.gov/.

Vance, A.J., P. Jones, and B.C. Strik. 2017. Foliar calcium applications do not improve quality or shelf life of strawberry, raspberry, blackberry, or blueberry fruit. HortScience 52:382-387.

Washington Blueberry Commission. 2017. 2 Feb. 2017. <http://wablueberrycomm.org/>.

Washington State University (WSU) AgWeatherNet. 2017. Historical weather data. 2 Feb. 2017. $<$ http://weather.wsu.edu $>$.

Wickham, H. 2009. 'ggplot2': Elegant graphics for data analysis. Springer, New York, NY.

Wilkinson, B. 1968. Mineral composition of apples IX.- Uptake of calcium by the fruit. J. Sci. Food Agr. 19:646-647. 